\title{
1. Fearing European unity and yearning for Asian cooperation: the early years
}

\section{Pascaline Winand}

It is true that Africa is Europe's hinterland for resources. But if Western Europe is to play its true part in an interdependent world, it is not enough if it remains oriented to the Atlantic and the Mediterranean. It must become a partner in the activities of traditionally civilized societies in India and China which are repositories also of intrinsic cultural and intellectual strength. Jean Monnet speaking to K. Krishna Moorthy (Moorthy 1984)

'The Indian Government has so far maintained a reserved, in certain cases, frankly hostile attitude toward the Treaty instituting the European Common Market' (CMA 1958e). These words were written in 1958 in the Council of Ministers of the European Economic Community. Two new European Communities, the European Economic Community (EEC) and the European Atomic Energy Community (Euratom), had just come into existence. They joined the European Coal and Steel Community (ECSC), which had taken its first steps in the summer of 1952. India had watched the gestation of the EEC with concern. The industrial Free-Trade Area envisaged by Britain as an alternative to the EEC also caused alarm in Indian official and business circles alike.

This chapter focuses on the first stage of the evolution of the attitudes of Indian governmental and business elites towards European integration attempts from the 1940s to the early 1960s. We examine Indian reactions to the failed negotiations for a European Free-Trade Area as well as Indian attitudes towards the gestation of the European Communities and the European Free Trade Association (EFTA). We then ask what Indian interests were likely to be affected by the creation of the EEC and what strategies India developed to defend them. Did India try to act within the framework of the GATT (General Agreement on Tariffs and Trade)? Did it side with other Commonwealth countries? How did Indian elites view the association of the overseas territories of EEC member states with the EEC? To what extent did India lobby EEC member states directly? Did 
Indian officials and business representatives organize trade missions to the EEC? Did Indian business and government circles conduct in-depth studies on the effects of the EEC and EFTA on Asian countries? We then inquire whether Indian strategies were successful and whether India contemplated other avenues for addressing the EEC challenge, including by promoting economic cooperation among Asian countries.

But to begin with, we consider the keen interest of Indian elites in regional unification in Europe and in other parts of the world in the first years after World War II and to what extent they reflected their hopes for improving Asian cooperation.

\section{INDIA, REGIONALISM AND THE INDIA QUARTERLY}

Concern regarding the EEC notwithstanding, some Indian elite circles had long been fascinated by regional organizations - existing or in the making - including a European Union, and their implications for cooperation among Asian countries. The Indian Council of World Affairs (ICWA), a prominent think tank in New Delhi with close ties to Indian officials, was at the center of such deliberations. The ICWA had been created in 1943 and soon became one of the foremost sources of ideas on foreign policy for the Government of India (GOI). Prime Minister Nehru was highly supportive of the organization. Just before India's Independence, ICWA organized the Asian Relations Conference in New Delhi from 23 March to 2 April 1947. The conference gathered together delegates from 26 countries, among whom were many leaders of independence movements. Pandit Jawaharlal Nehru presided over it and Mahatma Gandhi addressed its final session. Its aim was 'to provide a cultural and intellectual revival, and social progress in Asia, independent of all questions of internal as well as international politics'. It was also intended to foster Asian cooperation, possibly leading to an inter-Asian policy that would break the old pattern of isolation of Asian countries from one another under European colonialism (McCallum 1947, p. 13; interview with Director General ICWA, New Delhi, October 2011).

While Indian officials seemed tempted by regional cooperation in Asia, they also looked to other regions of the world for ideas, including Europe. Yet throughout the 1940s and until the early 1960s, India would continue to see Europe as being 'tainted by colonialism'. Some members of the EEC would gradually free their colonies during this period. But while French territories in India were freed without any problems over the years 1956 to 1962, India opposed French policy in Tunisia and Morocco in the early 
1950s and was a very early advocate of the liberation of European colonies in Africa in the framework of the United Nations (UN) (Kumar 1966, p. 53).

It is in this context that ICWA opened the pages of its journal, the India Quarterly, to a series of articles on regional endeavors by Indian and European authors. In 1946, Kavalam Madhava Panikkar, an Indian journalist who would become ambassador to France in the late 1950s, ${ }^{1}$ found the idea of regional organizations appealing. Yet he thought that their role was severely constrained by the United Nations Charter and the veto power of the members of the Security Council. In the field of security, he feared that they might 'become merely another instrument for the effective assertion of the supremacy of [. . .] Great Powers' such as Britain, who had interests in many regions. The regional organizations would be 'unable to enforce sanctions' against them and could 'even be used to uphold and consolidate [their] influence and authority'. He saw some merit, however, in having regional councils tackle the economic, social, health and human rights objectives of the Charter, where the 'Great Powers' would not exercise their veto power. Their work would be most needed, he felt, in 'the regions further away from Europe and America' (Pannikkar 1946). G.A. Johnson thought that in the UN Charter regionalism was seen 'as something to be tolerated rather than encouraged'. He believed that a European Union embracing the whole of Europe bar the Soviet Union and perhaps Britain was unlikely at the time. It 'would revolve around Germany' and bring back fresh memories of 'Hitler's New Order' which had been 'the culmination of the United Europe projects' (Johnson 1946). ${ }^{2}$

In 1949 Dr. Girija Mookerjee, who would later found the European Studies program at the Indian School of International Studies and Jawaharlal Nehru University, went back all the way to the Roman Empire and Charlemagne in an article that mentioned past attempts to unify Europe or federate the West by Aristide Briand, Clarence Streit, Nazi Germany and Richard Coudenhove-Kalergi. Dr. Mookerjee also examined the recent creation of the Organisation for European Economic Co-operation (OEEC), the Brussels Pact and the Council of Europe. 'Thus, on paper at least', he commented (Mookerjee 1949), 'a European Union has been formed although not with so much conviction that it will finally lead to the creation of a United States of Europe on the pattern of the U.S.A. which seems to have been the ideal set by most of the Europeanists'. Roadblocks towards the ideal were manifold. Not only did many European peoples not embrace 'the idea of Europe as a geographical entity', but their long history made it unrealistic to expect them to evolve along the same lines as an American federation. He could not fathom a 'stable European Union, 
unless both France and Germany - the two countries which really count on the Continent - have been definitely reconciled'. A Franco-German union would have to form the very heart of the European Union but he felt that 'such a prospect [was] very distant indeed!' especially as 'those Frenchmen who [thought] in terms of a European Union at all, [did] so, as a barrier against Germanic expansion and not so much as a bloc of the West European States against Russia'. Another obstacle was the 'complicated structure' of the British Commonwealth which, in spite of the loss of Britain's Indian Empire, made it difficult for Britain 'to identify herself completely' with European continental countries. Without 'the full participation (that is to say, integration) of Great Britain in the working of such a Union' it would never be able to muster enough 'prestige or reality'. Mookerjee concluded (Mookerjee 1949):

That is why, although much discussion is going on in the European press and radio on the question of European Union [. . . it is [. . ] much ahead of public opinion and there is no reason to believe that, even if a Western Union is somehow brought into being, it will have popular support.

Mookerjee was right about the importance of the Franco-German couple for a European Union, but the 1950 Schuman Declaration, which led to creation of the first European Community, showed that the first steps towards a European Union were not such a distant prospect after all.

The Indian elite also considered attempts to unify other parts of the world than Europe as a potential guide to organizing an Asian Union. Again in the India Quarterly, H. Venkatasubbiah, industrial correspondent for The Hindu, looked to the 1948 Organization of American States (OAS) for lessons in the creation of 'an Asian union as a permanent regional organization' (Venkatasubbiah 1949a). The background to this was the January 1949 New Delhi conference on Indonesia that had brought together Asian governmental leaders and had incidentally evoked the need for a permanent organization. The third resolution of the conference stated 'the opinion that participating Governments should consult among themselves in order to explore ways and means of establishing suitable machinery, having regard to the areas concerned, for promoting consultation and co-operation within the framework of the United Nations' (Venkatasubbiah 1949b). Nehru had concluded the 1947 Asian Relations Conference by saying that cooperation was needed to allow Asia to play its rightful part in the world. Venkatasubbiah saw a number of problems in creating an Asian Union. How should one define the geographical limits of the region? In Indonesia, Indo-China and Malaya 'the problem of sovereignty' was 'itself unresolved as yet' (Venkatasubbiah 1949b). As for Japan and Korea, their membership in an Asian Union depended on 
an agreement between the US and the USSR. Many Asian states were also tied to non-Asian powers 'by constitutional or treaty provisions' or economic dependence. Japan and India led Asia in terms of development 'but neither of them was in a position to extend financial aid to underdeveloped countries in the region' (Venkatasubbiah 1949b). In spite of all of these obstacles, however, Venkatasubbiah thought that a permanent Asian organization would be (1949b):

[...] well suited to pool existing economic resources and arrange for the supplementary foreign aid - as in the case of the European Recovery Programme - on agreed principles. The fear that extra-continental political influence will follow economic aid could be largely allayed if development with foreign capital proceeded under organizational rather than bilateral auspices.

In addition to bringing the necessary resources without being subject to external political control, the organization could also work together with the UN Security Council to peacefully resolve disputes in the region. As for its structure, the Asian Union could not be modeled fully on the OAS as it had evolved over many years and a fledgling Asian Union would have to be developed step by step, starting off with fewer institutions than the OAS (Venkatasubbiah 1949b).

The India Quarterly continued to examine cooperation in Asia in 1951, with a special emphasis on economic cooperation and the activities of the Economic Commission for Asia and the Far East (ECAFE), a regional economic commission of the UN created in 1947, which P.S. Lokanathan thought had 'achieved the singularly valuable purpose of getting together Governments of Asia and the Far East on a common forum to discuss and consider their common problems with a view to finding solutions' (Lokanathan 1951). As we shall see in this chapter, about ten years later a key Indian official would root his reflections on Asian economic cooperation in a careful appraisal of the achievements of regionalism in other parts of the world, including in Europe.

\section{EUROPEAN ECONOMIC COMMUNITY, FREE- TRADE AREA AND EUROPEAN FREE TRADE ASSOCIATION NEGOTIATIONS}

In spite of the early interest in a European Union and an Asian Union in the 1940s and early 1950s, the creation of the first European Community, the European Coal and Steel Community (ECSC) seemed to go largely unnoticed, including in the India Quarterly. The new Community comprised six European countries: Belgium, France, Germany, Italy, Luxembourg 
and the Netherlands. By contrast, the European Economic Community (EEC), with the same membership as the ECSC, triggered interest and fear in Indian governmental and business circles, even before the Rome Treaty entered into force. The British plan for an industrial free-trade area (FTA) which would include the six ECSC countries as a single unit and those OEEC countries that agreed to join, was also cause for concern.

\section{European Free-Trade Area, the Commonwealth and India}

During the negotiations for the creation of a European Economic Community and a European FTA, the United Kingdom High Commissioner in India and the United Kingdom Trade Commissioner transmitted secret and confidential telegrams to the Commonwealth Relations Office in Downing Street enclosing Indian reactions to both projects. The British Chancellor of the Exchequer had recently broached the idea of a European FTA at a Commonwealth Ministers' meeting in Washington in September 1956. He insisted that no final decision had yet been reached in London on the FTA, and welcomed input from Commonwealth countries. He said there was some urgency in this as the six countries negotiating the EEC ('the Six') could make decisions potentially harmful to British and Commonwealth interests; the FTA would also soon be discussed in an OEEC working group. In case Britain decided to go ahead with it, the Commonwealth Office requested UK High Commissioners to promise Commonwealth countries that Britain would keep in touch with them regularly and use British influence to protect their interests (DO 1956a). The Indian reactions were soon forthcoming.

The GOI was generally favorable to an FTA, as long as it fostered freer trade and payments and did not severely damage the Commonwealth preference system and Indian export prospects. India particularly feared the inclusion of European colonies and dependent territories in the FTA as their products were competitive with Indian ones. Delhi expected that Britain would put pressure on the Six to protect Commonwealth interests and hoped that the FTA might increase capital flows to developing countries (DO 1956b).

\section{India's First Official and Business Reactions to the Creation of the EEC}

The creation of a customs union among the Six caused more anxiety in Indian official and business circles than the FTA. Indian officials initially worried that Indian cotton-textile exports to Europe might be displaced by EEC producers selling to other EEC producers. By February 1957, there was anxiety in Delhi 'about the speed with which the Six were settling their 
arrangements for a Customs Union' and fear of the 'repercussions through preferential treatment of the French colonies'. India planned to have the EEC intensively scrutinized in GATT for its trade-diverting effects, especially towards developing countries. In fact, when the Six asked GATT to be allowed to form their customs union, India was part of the group of countries which argued that the EEC would contravene the GATT's aim to support free multilateral trade (Kumar 1966, p. 54). British officials told their Indian contacts that this might also be a good time to make Indian 'views known in Europe and particularly in Germany' (DO 1957a).

Meanwhile, the Indian National Committee of the Commission on Asian and Far Eastern Affairs (CAFEA) of the International Chamber of Commerce (ICC) suggested including 'A Study of the Schemes for the European Common Market and European Free Trade Area and their implications on the Trade and Economies of Asia and the Far East' in the ICC work program for 1957-59. The CAFEA agreed to do so during its May 1957 meeting in Naples (CMA 1960d). That same month, the Indian Ministry of External Affairs delivered an aide-memoire to the ambassadors of the Six with India's first reactions to the EEC. A copy was also given to the British in hopes that the UK would back Indian requests as 'this would count even more than Indian appeals' to the EEC. Indian concerns were many. The GOI feared that the creation of the EEC would result in higher tariffs and quantitative restrictions vis-à-vis the rest of the world, including in agriculture. Delhi found the decision of the Six to associate the French, Belgian, Italian and Dutch overseas territories with the EEC particularly unpalatable. For India, the association was a violation of GATT principles and constituted a ploy for EEC countries to have a privileged access to the markets of these territories and to 'hinder the legitimate political aspirations' of their peoples. The creation of a special investment fund for the overseas territories further threatened to skew the flow of EEC capital towards these countries to the detriment of other developing countries. The GOI accordingly hoped that the Six would lend a friendly ear to their concerns 'before any irrevocable decision' was taken (DO 1957b). This was bad timing: the Treaties of Rome had already been signed on 25 March 1957 and now awaited ratification by the Six.

The governments of the Six soon worked out an agreed reply to the GOI. The Belgian government confidentially transmitted a draft of the reply dated 18 June to British governmental contacts, which was duly sent by the British to the United Kingdom High Commissioner in Delhi. The Belgian government declared itself surprised by the Indian aide-memoire. It extolled the intentions of the EEC to liberalize trade in the EEC and in the world, and had no doubt that it was consistent with the GATT. The association of EEC overseas territories would be to the benefit of these 
territories and would encourage their economic and social development. Products from these countries would enter the EEC without any obstacles after a transition period and benefit from a special investment fund. Why could India, and other countries which had 'made themselves the champions of aid for underdeveloped countries', not view with sympathy 'an effort as vast, practical and disinterested' as the association of overseas territories with the EEC? The Belgian government declared itself 'deeply conscious of its obligations to the people of the Congo' and 'was firmly resolved, as (were) its partners, to pursue the development of the African peoples with the view to bringing them to the full development of their moral, material and political strength and putting them in the way to bring to humanity the benefit of their co-operation in peace, civilization and progress' (DO 1957c, d, e). Similar letters to the Belgian one were sent on behalf of the five other member states.

This high-handed defense of the intentions of the Six did not calm Indian apprehensions. On 26 September, the Indian prime minister reportedly told a Japanese correspondent in New Delhi: 'I do not approve of the common market scheme in Europe. I am afraid that the scheme will mean exploitation of colonies of European countries' (DO 1957f).

\section{European Free Trade Association: Negotiating Compensation for India}

The British Commonwealth Relations Office immediately worried that Nehru had also been referring to the possible association of overseas territories with the proposed EFTA. The Commonwealth Relations Office asked the UK Commissioner to make clear to Delhi that the industrial free-trade area would be confined to Europe and would exclude dependent overseas territories of the UK and the Six (DO 1957g). The FTA never saw the light of day, however. Macmillan's fears of the 'Common Market coming into being and the Free Trade Area never following' (Macmillan 1971, p. 435) were realized. The British now fell back on the creation of a seven-country association, the EFTA between the UK, Norway, Sweden, Denmark, Switzerland, Austria and Portugal, which caused further worry in Delhi.

The proposed EFTA convention required the UK to reduce and progressively remove duties 'on all industrial goods and raw materials (as well as certain agricultural goods) imported from other EFTA countries' (BT 1959a). For India and several other Commonwealth countries this meant that certain margins of preference guaranteed in trade agreements with the UK would have to be reduced and eventually abolished. The UK accordingly approached India, Australia, New Zealand, South Africa, Pakistan and the Federation of Rhodesia and Nyasaland to obtain their agreement 
to waive some of the preferences their imports benefited from in the UK under their trade agreements. As the volume of trade affected would be relatively small, Indian officials were rather forthcoming with their British contacts in trying to find a satisfactory solution. What made their task difficult was the opposition of a section of the Congress Party to waiving imperial preferences (BT 1959b). To sell an EFTA waiver to the Indian Parliament, India would need to be given compensation for waiving her rights under the 1939 Indo-United Kingdom Trade Agreement on certain preferences in relation to EFTA, at least on paper (BT 1959c). Indian officials accordingly bargained for safeguards and compensation so that Indian goods would not be disadvantaged, compared to EFTA goods. Delhi also obtained an assurance from Britain that the elimination of preferences to Indian goods [would] not involve any increase in duties at present levied on Indian goods' (BT 1960a). Indian officials banked as well on the forthcoming tariff negotiations in GATT to negotiate further compensation. When questions were raised in the Indian Parliament about the consequences for India of waiving her right to imperial preference in relation to EFTA, the Indian minister of commerce had a readymade answer. India had agreed to the waiver, he said, 'subject to certain safeguards and reservations to the elimination in stages of Tariff preference provided under the Indo-United Kingdom Trade Agreement, 1939, for Indian goods in the United Kingdom market vis-à-vis import in the United Kingdom' of EFTA products. The waiver was 'not likely to have an adverse effect' on Indian exports to Britain (BT 1960b). Yet India was the last country to agree to the waiver, and this in spite of reminders from the British side that the British government was keen to ratify the EFTA convention which had been initialed in Stockholm in November 1959 'as soon in 1960 as possible' (BT 1960c, d).

\section{INDIAN GOVERNMENTAL AND BUSINESS CIRCLES AND THE FIRST YEARS OF THE EEC}

\section{Using the GATT and Lobbying EEC Member States}

The attitude of India towards the newly created EEC was anything but positive. This led to a number of actions in GATT and to direct representations to the Six. Indian concerns continued to center on the impact of the association of overseas territories to the EEC on Indian tropical exports. It seemed that India was ready to lead Asian and African developing countries in defending their interests vis-à-vis the EEC. The EEC Council, in a September 1958 note preparing member states' ministers for 
a meeting of the International Monetary Fund (IMF) in Delhi, recounted that in recent GATT negotiations the Indian Delegation had mostly sided with the UK and the Commonwealth in attempts to shackle the EEC to permanent control mechanisms. India had also been very active in the GATT Working Group on Overseas Territories in criticizing the association of overseas territories with the Common Market. The EEC member states' representatives argued that the association was compatible with Article XXIV of the GATT on customs unions and free-trade areas. They contended that they could not be faulted for seeking to increase production in the overseas territories, as this was a way of promoting their economic development and prosperity. The Six also insisted that they would not exclusively import tropical products from the overseas territories and would certainly need to import such products from other countries as well. In spite of these assertions, the Working Group did not make much progress. The GATT Intersessional Committee therefore decided that it would be better to defer the discussion on the compatibility of the Rome Treaty with Article XXIV and to use Article XXII on consultation instead in an effort to focus on concrete measures that might alleviate the consequences of the creation of the EEC for certain members of the GATT. Soon India made moves to open negotiations on tea and unmanufactured tobacco (CMA 1958a). ${ }^{3}$

Tea, India insisted, made up 23 percent of all Indian exports. In 1956, India exported 4,300 tons ${ }^{4}$ of tea to the six members of the EEC, while these countries also imported about 6,000 tons of tea via the UK. A high EEC common external tariff (CET) on tea and the preference enjoyed by the overseas territories associated with the EEC could severely damage Indian exports to the EEC. India also exported great quantities of unprocessed or raw tobacco to the EEC (CMA 1958b). In addition, India wished to join the UK consultations with the EEC on coffee as it exported 75 percent of its coffee to the EEC (CMA 1958c). Yet the Six, arguing that they needed concrete cases to start the negotiations, took quite some time in agreeing to a date for the opening of consultations on tea, coffee and tobacco with India and other countries. This did not go down well with British, American, Indian and Rhodesian delegates who all insisted that negotiations must start as soon as possible (CMA 1958d). Consultations on tea eventually took place in Geneva in October 1958 with India, Ceylon, Indonesia and Pakistan. In February 1959, these four countries asked the Six to give a written answer to the concerns they had expressed in a joint memorandum to them. Again, it took some time for the EEC member states to agree on an answer, which was eventually transmitted to the four countries at the fourteenth session of the GATT on 19 May 1959 (CMA 1959a). The Six insisted that they were keen to develop trade with 
India, Ceylon, Indonesia and Pakistan as their economic development would no doubt lead to an expansion of trade prospects. The Six argued, however, that the tea exports of these four countries to the EEC made up only a small part of their total exports. For example, India exported 158,234 tons to the UK and only 3,444 tons of tea to the Six. (In arguing this, the Six seemed to ignore the earlier contention by India that the EEC also imported Indian tea via the UK.) The Six also insisted that the EEC CET of 35 percent and internal taxes would not necessarily lead to diminishing imports of tea from these countries into the EEC. For example, the Netherlands was an established market and consumer tastes and consumption would change little even though duties would go up as a result of the entry into force of the Common Market. As for Germany, it was an expanding market for tea, Italy was a new market, and the Common Market would in these two cases lead to a reduction in duties, which could increase consumption. As for concerns about the effects on Indian exports of the EEC preference for tea produced in the Belgian Congo, the Six argued that such production was unlikely to increase much because of local conditions in the Congo and that EEC consumers preferred other tea qualities (CMA 1959b).

\section{Indian Business and Government Deal with the EEC Challenge: Studies, Missions and Bilateral Agreements}

In parallel with the GATT negotiations, Indian businessmen scrutinized the consequences of the establishment of the EEC for their interests. The Committee of the Commercial Counselors of the EEC countries, which regularly met in New Delhi, found a note of the Federation of Indian Chambers of Commerce and Industry (FICCI) 'on the European Common Market and its possible repercussions on the countries of the Afro-Asia region' highly illustrative of the 'negative attitude' of India to the EEC. The counselors felt this attitude was 'no different than that of other less developed countries' and was 'built on [Indian] apprehensions and fears for the future development of her export of raw materials to the "Six" and of her slowly developing position as exporter to Asian-African countries of her industrial products'. As India was a member of the Commonwealth, 'her attitude (was) undoubtedly influenced by that of the leader of that group of nations, i.e. the United Kingdom'. FICCI's note was discussed at the Afro-Asian Economic Conference in Cairo in December 1958. The federation feared that the EEC would impose higher tariffs and other restrictions against outside countries. Preferences for EEC overseas territories, the establishment of an investment fund to the benefit of these territories, EEC agricultural policies and 'monopolistic tendencies', would 
damage the trade and investment prospects of countries of the Afro-Asian region. To counter such developments, the FICCI proposed to work through the GATT to press EEC countries to modify the Rome Treaty in such a way that it would not undermine third-countries' exports. The Rome Treaty must also include checks against monopolistic tendencies and its provisions on agriculture must be amended. Finally, 'the countries of the Afro-Asian region should also devise schemes for promoting trade and economic cooperation among themselves'. A study on the EEC and Indian agricultural exports sponsored by the GOI and published in May 1959 added to the sense of urgency. While only tobacco and vegetable oils exports were likely to be severely affected, the report argued that the trade imbalance between India and the EEC meant that 'even a slight fall in India's exports should be of serious concern'. The EEC counselors in Delhi completed the analysis by emphasizing that the trade imbalance between India and the EEC was even greater than between India and EFTA, while trade between India and Communist countries was balanced. If India continued to import from the EEC, it was because these imports were key to its economic development. There was the danger, however, that the Soviet Union would exploit Indian financial difficulties to further its own goals. This, they feared, could undermine Indian political institutions and India's orientation towards the West (CMA 1960e).

It is against this background that a Goodwill Trade Mission organized by FICCI visited France, Germany and Italy as part of a world tour in the spring of 1959. The Mission recommended a number of improvements to Indian export policy. Its report was read with great interest by the Committee of the Commercial Counselors of the Six in Delhi who duly transmitted it to the EEC Commission in Brussels. In reaction to complaints by foreign buyers that changes in Indian export policy were too frequent, the Goodwill Trade Mission recommended greater continuity in such policy. Its report also urged an improvement in the 'quality of processing and finishing of Indian textiles', a better adaptation of Indian jute industry to consumer tastes abroad, more publicity activity on the part of the Indian Tea Board, a strengthening of the commercial sections of Indian diplomatic posts, and more vigorous efforts to promote certain Indian products (CMA 1959c).

The FICCI Mission report was also read in governmental circles. In 1959, the GOI consistently pressed EEC countries and, in particular, Germany, France, Belgium and Italy, whose exports to India had greatly increased and with which India had high trade deficits, to increase their imports from India. Delhi also asked for trade discussions with the Six to find ways of boosting Indian exports to the EEC. The Indian Ministry of Commerce and Industry warned an Italian official in no uncertain terms 
that such discussions were essential. Otherwise India would find herself compelled to take measures to restrict her imports from such countries. The counselors of the Six in Delhi took this warning seriously and feared that India might grant new Indian import licenses sanctioning imports from third countries and thereby displacing imports from EEC member states. Even though the counselors maintained that Indian traders were mostly to blame for the poor performance of Indian exports to the EEC, they nonetheless noted that there was an inherent trade imbalance between EEC countries and the United Kingdom. The EEC must try to make adjustments for the fact that a great deal of Indian exports to the UK were not consumed in Britain but re-exported to Europe, and, in particular, Germany (CMA 1959d).

Indian businessmen and officials expressed concern at the effects of the EEC on India's exports at a meeting of the Export Promotion Advisory Council in New Delhi in mid-September. Mr. B.M. Chinai from FICCI said that 'all kinds of regional groupings' impacted Indian export trade, including the Common Market and EFTA. Latin America was also moving towards regional arrangements. He criticized the GOI for not making it clear to the business community if the government was working on a 'close study' of the impact of such regional arrangements and counseled 'increased association of the business community in these matters'. Indian Director-General for Foreign Trade, Krishen Behari Lall, replied that he felt that India need not fear the European Common Market (CMA 1959e): 'As the economies of these countries could develop at a faster rate, they would require more of the commodities they were importing. If these countries concentrated on industrial production of higher forms, they would need simpler manufactures from India and other countries'. The real crux of the matter was 'to what extent India would be able to secure her share in their increased requirements'. Indian business must find new business tactics and marketing. Mr. Lall added that the delegation of officials and businessmen, which would soon go to Europe as announced at the meeting by the minister of commerce and industry, would seek contacts with business and governments to balance trade between India and certain European countries. If there were no reaction 'the delegation would tell the countries that India would be forced to arrange imports to suit the order of exports' (CMA 1959e). Lall added that European governments had identified the inadequate 'commercial competence' of Indian business as the main reason for Indian failures to increase its export trade to European countries. The delegation, he insisted, 'was proposed to be sent in order to prove to these Governments that their statement was incorrect and to show that Indian business was not only competent but also anxious to expand trade with them' (CMA 1959e). India's finance 
minister, Mr. Morarji Desai, was more forthright in his comments at the Commonwealth Finance Ministers Meeting in London at the end of September. The Common Market, he said, might lead to problems for Indian exports, especially textiles, and might push India out of EEC markets and force her to find markets somewhere else. The Indian minister of commerce, Mr. N. Kanungo, had earlier told the Indian Parliament that he feared that the Common Market would have some negative consequences on Indian trade but that 'no such effect had so far arisen'. Asked whether the government would be entering into trade agreements with EEC countries, Mr. Kanungo said that India was indeed attempting to negotiate special trade agreements with these countries (CMA 1959e).

The FICCI Mission in the spring was duly followed by a visit of Indian officials and businessmen to Europe in the autumn, with a view to negotiating trade agreements with Belgium, Germany, France, Italy and Switzerland. Letters were exchanged with each capital, which included the creation of a mixed committee with each of the countries and India to find practical measures to increase trade. In Brussels, the idea of an Indian diplomatic mission to the EEC was mooted during a meeting with Jean Rey, the EEC Commission's Commissioner for External Relations (Lall and Chopra 1984, p. 11; Giri 2001, p. 85). Mr. Krishen Behari Lall, who headed the delegation, would later become the head of the Indian Mission to the EEC at the beginning of 1962 in the midst of British negotiations to join the EEC. As a result of the Lall visit, FICCI also began looking into the possibility of opening an office in Western Europe to promote trade and assist European investment in new Indian companies.

In the wake of the Lall visit, Mr. Chandra, the Indian deputy minister of commerce and industry, spoke at the annual meeting of the Indo-German Chamber of Commerce in Bombay. He remarked that while India imported many industrial goods from West Germany for her economic development, it mostly supplied primary commodities or secondary goods to Germany. Indian exports to Germany had 'more or less remained static'. During discussions in Bonn, Germany and India had both resolved to remedy the unbalanced trade between their countries. Germany agreed to help Indian producers manufacture products more suitable to the tastes of German consumers by encouraging 'contacts with the best German designers, stylists and fashion experts' (CMA 1959d). Quotas for the imports of various Indian goods would be discussed in a newly created Indo-German Commission. The deputy minister also referred to already existing collaboration with Germany, citing the Rourkela Steel Plant and the production of Mercedes-Benz trucks in Jamshedpur by TELCO. He complained that quotas, high tariffs and fiscal levies prevented developing countries from exporting to 
developed countries. 'India must earn sufficient foreign exchange to pay back the credits advanced to her and yet have a surplus for purchasing more capital goods from the countries participating in her development', he concluded (CMA 1959d). This would later be repeated like a mantra in negotiations with the EEC. Striking a different note, the Indian minister of commerce and industry told the Indian Export Promotion Council and the Import Advisory Council that India had to lift its game to further increase exports. He blamed bureaucratic sluggishness and a lack of decentralization in the GOI's attempts to increase exports via advertising and incentive measures (CMA 1960a).

Also after the Lall visit, former Indian Ambassador to France, K.M. Panikkar, who, as we have seen, had already written in the pages of the India Quarterly back in 1946 on regional organizations, was reported in The Times of India to have extolled the virtues of the EEC, 'a development of vital character for the world'. The EEC had led to a 'reversal of alliances' with Germany and France leaving behind 'their old animosities, knowing that if they stood alone they would count for nothing, especially in the economic field' (CMA 1959d). He felt that political unification would soon follow in the footsteps of economic union and that the EEC member states' 'union into what would be a confederation of States would put them in a position of equality with America and the Soviet Union'. This would be especially so, if they could 'develop the resources of Sahara'. Britain would not be kept out of the EEC 'for long'. But the Six 'felt that their total unification must precede any effort to open the door to Britain and any other countries' (CMA 1959d). Mr. Panikkar has been proven by events to have been overly optimistic about the chances of a proximate entry into the EEC for the UK while his predictions of 'total unification of the EEC' give pause for thought even today.

In 1960 the Commonwealth offered a convenient framework to vent Indian frustrations about the Common Market and EFTA. Senior economic officials of the Commonwealth met before the Commonwealth Prime Ministers' Conference in March. Among the topics they discussed was the impact of the EEC and EFTA on their trade interests. The Indian Delegation to that meeting was suited to the task, bringing together $\mathrm{Mr}$. S. Ranganathan, Union Commerce and Industry Secretary, as delegation leader, and Mr. T. Swaminathan, a nominee of the Reserve Bank and the Indian Commissioner-General for Economic Affairs in Europe. To prepare for the meeting, the Indian Union Commerce and Industry Ministry and the UK Board of Trade wrote an analysis on the potential effects of European economic integration on Indian trade interests. The study argued that certain Indian exports would be severely hit and their future expansion hemmed in. It studied the effects of four products in 
particular: tea, coffee, cotton cloth and leather. Hopes that the EEC and EFTA would be kept separate and thus, compete with one another, now also seemed unfounded. Indian officials harbored a particular fear that EFTA and the EEC might collaborate with one another, further undermining the prospects of Indian exports. India seemed caught in a bind. On the one hand, it could not object to British participation in an FTA or 'in any arrangement designed to bring the area closer to the European Common Market' as 'any development which [would weaken] Britain's position as a major trading nation [would] be detrimental to the entire Commonwealth' (CMA 1960b). On the other hand, India could not agree to an arrangement that would sacrifice its own economic interests on the altar of Commonwealth economic prosperity. Indian officials accordingly sought to mitigate adverse effects to their trade 'through counterbalancing Commonwealth preferences to be given by the UK to India' within the GATT (CMA 1960b). Soon these tactics would have to be revised as the UK contemplated not just getting closer to the Common Market: Britain was considering actually joining the European Communities.

By the end of 1960, P. Chentsal Rao and H.L. Gupta were ready to submit their report on the 'Implications of the European Common Market and European Free Trade Association on Trade and Economies of Asian Countries' to the Commission on Asian and Far Eastern Affairs of the ICC meeting in Karachi. As we have seen, India had been pressing for such a study since 1957. The report was the result of many discussions and their conclusions were that the efforts of Asian countries to address the challenge of the EEC in GATT had so far 'not led to any concrete results'. They counseled action in GATT to modify the EEC common agricultural policy 'with its paraphernalia of quotas, a common marketing organization and minimum prices' and to review the association of overseas territories with the EEC. Every effort should also be made to maintain the EEC common external tariffs at a reasonable level. If possible, the tariffs ought to be maintained as closely as possible to those of the low-tariff EEC member states. Under no circumstances were they to 'exceed the weighted arithmetic average of the duties levied by EEC member states' (CMA 1960d). The authors were outraged at the 35 percent tariff on tea and found 'no justification' for it being set at such a high level. They also contemplated the creation of a free trade association in Asia, at least among some Asian countries (CMA 1960d). This last theme would soon be revisited in fuller detail in what came to be known as the Lall Report.

India met with limited success in negotiations with the EEC in GATT. Representatives from the EEC Commission and the member states argued that they were only required to propose compensation to India where 
the EEC CET would lead to a higher tariff than the original tariffs of the member states. India, on the other hand, deplored the lack of an offer from the EEC for certain products which were vital for its economy and insisted that, in particular for manufactured and semi-manufactured goods, the CET was higher than the initial tariffs of the member states. In the end, the tariff on tea was reduced to 18 percent as were tariffs on some other tropical products. This did not fully satisfy India, who now banked on the forthcoming Dillon negotiations in GATT to continue to press its case (CMA 1962a).

On the EEC side, the commercial counselors in Delhi kept sending regular reports to Brussels. They examined the competitiveness of Indian cotton products and concluded that while salaries in India were mostly lower than in Europe, except for Spain and Portugal which had even lower salaries than in India, low productivity undermined Indian competitiveness: one European worker seemed to be able to do the work of 'six to seven Indian workers'. This meant that Indian export prices were higher than Japanese and Chinese prices (CMA 1960c). This was an argument that their Indian counterparts had been making for some time. From an Indian perspective, the decline of EEC imports from India was seen as a 'direct consequence of the entry into force of the Rome Treaties'. The 'enormous trade deficit with West Germany' and protectionist measures from Bonn against several Indian goods were particularly sore points. While Indian exports to the EEC declined (except for Belgium), Indian exports to communist countries mostly increased via payment scheme agreements in rupees. Russian, Rumanian and Yugoslav trade missions visited India to conclude trade agreements and propose loans (CMA 1961a). From an EEC perspective, this activity on the part of communist countries boded ill for the economic and political interests of the EEC and of the West. It became clear that India was of strategic importance, not only to the West, but to the communist bloc also. The EEC would increasingly have to contend with trade competition from the communist bloc in India.

Western Europe and the UK were of key importance to India too. In light of the growing and recurrent trade deficit with this region, the Indian Chamber of Commerce in Calcutta devoted a detailed study on India's export trade with it. The Chamber argued that in the past, trade deficits had not mattered much as India could draw on its sterling balances and benefit from loans and credits from the USA and various other donors. But sterling balances were now very low and loans and credits could only get you so far. What was needed was a substantial increase in Indian exports to earn sufficient foreign exchange to meet the requirements of India's Five-Year Plans for development. Both the EEC and EFTA were 
creating problems for India as higher tariffs and other restrictions hurt Indian trade. But 'trade, being a two-way affair', European countries had an interest in having India earn sufficient foreign exchange to enable her to import capital goods from them. The Chamber examined India's trade with several European countries, including EEC member states and the UK. India's negative balance of trade with West Germany was a particular concern. It resulted mainly from sizeable Indian imports of machinery, plant and industrial equipment from that country. Yet the Chamber felt that there was room for supplying West Germany with a lot more items that this country currently imported from other parts of the world. Even though the German government did not appear ready to negotiate on hard-core items such as textiles, India could, for example, increase its exports of tobacco if it succeeded in improving its quality. At present, German manufacturers found 'Indian tobacco somewhat harsh in taste and of poor burning qualities'. On the whole the Chamber concluded that there was a lot of scope for exporting more goods to Europe and for diversifying the range of Indian exports. European countries were 'passing through a period of great prosperity and in the coming years, their standard of living which [was] already high [was] bound to improve still further' (CMA 1961b). This could mean an increase of imports from raw materials and manufactured products. India could, for example, cater for the growing iron needs of the steel industry in Italy and Germany. Exports of coffee, handloom fabrics, handicrafts, coir mats, carpets as well as engineering goods could all be increased, especially if the GOI worked hand in hand with Indian business (CMA 1961b).

Commerce Minister M. Kanungo appeared to vindicate this hopeful assessment of Indian export prospects when he told the Indian Parliament that there had been 'no loss' in Indian export trade since the creation of the Common Market. 'In fact', he said, 'export to these Common Market countries has improved somewhat'. Meanwhile, Sir Paul GoreBooth, UK High Commissioner in India, spoke at the annual FICCI conference in March 1961 of a possible United Kingdom association with the Six. The commercial counselors reported that the conference had shown a 'benevolent understanding of European problems' (CMA 1961c). Soon, the atmosphere changed, however, when it became clear that the UK would apply for membership. Around the same period the future Indian Ambassador to the EEC was busy writing a report on the future of Asian economic cooperation rooted in a sophisticated analysis of regional endeavors in other parts of the world. This included the EEC and EFTA. 


\section{THE LALL REPORT: PLANNING FOR ASIAN ECONOMIC COOPERATION AND ADDRESSING THE EUROPEAN CHALLENGE}

As we have seen, Lall had been very active during the previous years in defending Indian interests against the EEC. He was to play a key role again in defending Indian positions during the negotiations for British entry into the Common Market. He had also been active in promoting regional cooperation among the countries of the UN Economic Commission for Asia and the Far East (ECAFE), which had recently held a conference in New Delhi from 26 October to 3 November 1961. During that conference, EEC countries in attendance, such as West Germany, the Netherlands and France, asked eminent Dutch economist Professor Jan Tinbergen to explain the advantages of EEC prosperity for imports from third countries (CMA 1961d). Back in September, during a meeting in Bangkok, Lall, who was then still Special Secretary of the Indian Ministry of Finance in New Delhi, had written in a 'personal capacity' a dense and detailed document. The report, which was kept secret at the time, was written together with two experts from Thailand and Japan. The German Embassy gave a copy of it to the EEC commercial counselors in Delhi in March and it was duly transmitted to the EEC Commission in Brussels.

The Lall Report showed a good knowledge of regional endeavors in other parts of the world. In Western Europe, the ECSC was praised as 'one of the decisive steps' in regional coordination. With the creation of the EEC, EFTA and future collaboration between them, the authors remarked that economic integration in Western Europe was 'reaching a decisive stage of fulfillment'. They also considered initiatives in economic integration in Latin America, Africa, among Arab countries and of course in Asia. In spite of multiple obstacles, such as different degrees of economic development, 'rugged mountains and large stretches of sea', they found 'in Asian hearts a yearning for regional cooperation in diverse fields' (CMA 1962b).

This yearning had been exemplified in several frameworks. The authors referred back to the Asian Relations Conference in Delhi in 1947, and to the 1955 Asian-African Bandung Conference. Co-sponsored by India, Pakistan, Burma, Indonesia and Sri Lanka, Bandung had gathered together representatives from 13 African nations and 16 Asian countries. The conference had a political and an economic dimension. In the context of decolonization, the participants supported political self-determination, equality, mutual respect for sovereignty, racial non-discrimination and peaceful coexistence. It was one of the building blocks in the creation of the Non-Aligned Movement (NAM). But the conference also advocated 
more economic cooperation, inter-regional trade and industrial ventures, as well as the stabilization of prices of primary products. It was followed in 1959 by a meeting of five Asian governments to further the Bandung decisions. The authors noted that the Federation of Malaya, Thailand and the Philippines had recently created an Association of South East Asia. The UN ECAFE Committee on Trade had also provided a most useful forum for exploring economic cooperation in Asia, including by encouraging discussions with EEC and EFTA representatives.

However, all of these efforts and contacts had not yet resulted in much action. Lall and his co-authors thought that more practical cooperation was needed in Asia. This was essential as Asia had growing needs for the machinery, equipment, technical expertise and capital from developed countries to further its economic development. Development had to be stepped up to ensure that the Asian economy grew faster than its population. By helping to pool resources and increasing trade in Asia, an economic organization in the region could help such development so that Asia could continue to finance its imports. The Lall Report noted that the Asian region met 'only a third of its import requirements from within itself'. This was partly the result of old colonial patterns where Asian countries had more economic links with European metropolitan countries than among themselves. Thus Asian trade with third countries was more significant than trade within Asia. In addition, Asian exports to Western Europe and the US 'fell short of its imports from them'. The Lall Report resolved, if possible, to reverse this trend: Asia must increase its production and export surpluses, thereby developing its 'capacity to pay for its imports and also to service much needed credits [...] through increasing the volume, diversifying the range, and improving the quality and value of its exports' (CMA 1962b). This closely matched the line that the GOI actively plugged in its dealings with EEC countries: India could only finance its growing import needs by increasing its exports to the EEC. The question was now how best to negotiate with the EEC. What framework would be most suitable to obtain concessions? When was it best to negotiate alone and when would negotiating as part of a group of countries be the more effective strategy?

Indian efforts to negotiate with the EEC, or for that matter with EFTA, in GATT had 'so far not yielded a satisfactory solution', the report argued. 'Strict reciprocity in tariff negotiations between advanced countries on the one hand and developing countries on the other, hardly provides a sound basis for negotiating a mutually beneficial system of trading relationships between the two groups of countries'. (CMA 1962b). This was all the more so as several ECAFE member countries were not GATT members.

The Lall Report further paid special attention to commodity trade 
where action by the EEC and other such organizations could disadvantage Asian producers. The report recommended studies to evaluate the impact of policies in the rest of the world on the Asian commodity market. More importantly, it counseled policymakers to 'explore the form and content of trading arrangements likely to provide some satisfactory solution of the problems with which the region as a whole may be faced' (CMA 1962b). As we shall see, Lall and other Indian officials would persistently defend the conclusion of a trade agreement between India and the EEC and the conclusion of several such bilateral agreements with other Asian nations during the negotiations for British entry and thereafter. Yet an India-EEC agreement took a long time to come to fruition. The participation of India in a regional organization was also fraught with difficulties as the SAARC (South Asian Association for Regional Cooperation) saga would later demonstrate.

Turning again to the Lall Report: 'Asia cannot afford, except at the risk of injury to its vital interests, to keep away from the movement towards regionalization in trading relationship' (CMA 1962b). The solution seemed to lie in the creation of an 'organization for Asian Economic Cooperation' comprised of countries from the ECAFE region. The organization would have a Council of Ministers with 'plenipotentiaries of all member states' and benefit from the assistance of the secretariat of the United Nations ECAFE. It would work to expand mutual trade, reduce tariffs and other trade barriers in the region, develop 'new lines of production and trade in industrial, agricultural and mineral products', 'study problems of international commodity trade' and 'cooperate in the development of intra-regional transport and communication facilities' (CMA 1962b).

The report was a sophisticated and lucid analysis of economic problems facing Asia and offered practical solutions to address them. While concentrating on economic cooperation in Asia, though, it did not venture into the perhaps too sensitive terrain of Asian political integration, merely noting that Asian regional economic cooperation would be 'animated by a spirit of goodwill' and 'mutual respect for national sovereignty'. In looking at regional trends in Europe, it failed to notice that political unification was a key dimension of European integration. Although Indian officials already fully recognized the EEC as an important economic actor, the GOI would take some time to take it seriously as an actor of political significance. Growing pains in the European Communities themselves go a long way in explaining this state of affairs. 


\section{CONCLUSION}

The British application could be seen as ending the first stage of the evolution of India's attitudes towards European integration attempts in Europe after World War II. This first phase was characterized in the 1940s by early Indian interest in attempts at regional unification both in Europe and in other parts of the world, all with a keen eye to furnishing ideas for Asian cooperation. These early years showed interest with regional endeavors on the part of Indian elites specializing in foreign policy and closely tied to the GOI and also within the GOI itself. Regional organizations in other regions were analyzed, including regional cooperation endeavors in Europe. This was with an eye to learning from these to rebuild connections between Asian countries in the post-colonial period, possibly leading on to an Asian Union. Analyses of attempts to build a European Union focused on the difficulties of such an enterprise in light of recent German attempts to unify Europe under Nazi rule, Franco-German antagonism and British lack of identification with mainland Europe. Indian analysts also highlighted the uneasy relationship between regional organizations and the United Nations. While they saw some merit in using regional councils within the UN to deal with important economic, health and social questions at the regional level, they also feared that regional organizations might be utilized by 'Great Powers' such as the UK to assert their supremacy in one or several regions. In a context of decolonization, and with India having just acquired independence, Indian officials and analysts also tended to view Europe and European unification attempts as tainted with colonialism or neocolonialism. This was clear in Indian reactions to the first steps towards the creation of the EEC and especially the association of the EEC with the overseas territories of some of its member states.

In the mid-1950s, the British-led negotiations for a European FreeTrade Area occasioned cautious Indian reactions. India feared that an FTA might damage Commonwealth preferences, particularly if European colonies and dependent territories were included. At the same time, Delhi hoped that the UK would prevail on the six EEC countries ('the Six') to protect Commonwealth interests in the FTA. However, when these negotiations failed and the UK fell back on the less ambitious EFTA, India also changed tack, bargaining for compensation and safeguards for Indian products so that they would not be at a disadvantage vis-à-vis EFTA products.

The more menacing parallel negotiations for a European Economic Community caused alarm in Indian business and governmental circles that exceeded the relatively muted reactions to the EFTA talks. India's initial reaction to the creation of the EEC was to act within the frame- 
work of the GATT to try and protect its interests. A first strategy was to join with other countries, especially the UK and other Commonwealth countries, in arguing that the EEC was incompatible with the GATT as it would undermine free multilateral trade. The association of the overseas territories of EEC member states with the EEC was vigorously criticized as violating GATT provisions against preferences. It was also criticized as discriminating against the exports of those developing countries, which remained outside the EEC preferential area with its overseas territories. This association was further lambasted as no more than a throwback to the days of benighted colonialism. On a more constructive note, India also agreed to negotiate with the EEC on concrete measures to alleviate the effects of the advent of the new trading bloc on Indian exports such as tea, tobacco and coffee. When such negotiations seemed to be doing no more than marking time, India joined other GATT delegates to put pressure on the Six to speed up the process. A second strategy was to lobby EEC member states directly to obtain concessions in GATT and with the aim of concluding bilateral agreements with individual member states. West Germany, with which India had a large trade deficit, was one of the key targets here. Indian officials and business representatives also organized trade missions to Europe to establish contacts with European business and government circles leading to increased opportunities for Indian exports to the EEC. A fourth strategy was to use the Commonwealth to criticize the EEC and EFTA. These four strategies led to limited results in GATT and to some agreements with individual member states, but these were relatively minor achievements. India's large trade deficit with the EEC still needed to be urgently addressed. All the more so as India's sterling balances were low and she could not be overly dependent on grants and loans. How then could India best take advantage of the EEC market with its prosperous consumers and ensure that Indian products would be competitive in this market? Some key business analysts concluded that some of the best ways to earn sufficient foreign exchange to finance India's development plans were to increase Indian exports and to promote Asian economic cooperation.

The Lall Report showed a mixture of admiration for the achievements of the European Communities and EFTA in the domain of regional coordination and of frustration that Indian negotiations in GATT with EEC and EFTA countries had borne only the most meager of fruit. To reverse a trend where Asia imported more from Western Europe than it exported to that region, the Lall Report recommended producing more, diversifying and improving the quality of Asian exports as well as promoting practical economic cooperation among Asian countries. As strict reciprocity in GATT tariff negotiations between developed and developing countries 
had produced only limited results, the report also recommended exploring new types of trade agreements.

Meanwhile, EEC member states defended the association of their overseas territories in GATT, and accorded only marginal attention to India. This was so, even though some European diplomats warned that the Soviet Union might exploit Indian trade and financial difficulties to undermine Indian democracy and lure it farther away from the West. There was some concern also that India might retaliate against the EEC by granting import licenses to goods from other countries than EEC member states. By and large, EEC negotiations with India were limited to individual products in the GATT framework. There were also negotiations for bilateral agreements with individual member states, but no bilateral agreement between India and the EEC as a single entity. One of the reasons was that the EEC was still in the throes of defining its commercial policy. The negotiations for British entry would prompt the EEC to pay more attention to Indian concerns as Indian negotiators adopted yet more innovative strategies to meet the challenge of an enlarged EEC.

\section{NOTES}

1. He was also scholar and administrator with a research interest on European influence on Asia and had been taught at the University of Oxford.

2. In 1949, Jean Van Mensbrugghe wrote about the Benelux economic union concluded by Belgium, the Netherlands and Luxembourg (Van Mensbrugghe 1949).

3. 'Unmanufactured tobacco' is a classification of raw, unprocessed tobacco and some grades of partially processed tobacco. A more complete definition is available at: http:// ec.europa.eu/agriculture/markets/tobacco/reports/rep_en.pdf (p.5) (accessed 19/09/ 2012).

4. Indian statistics were collated at this time using the UK imperial system of weights and measures. One imperial ton (also known as 'long ton') equals $1,016 \mathrm{~kg}$ or 1.016 (metric) tonne.

\section{REFERENCES}

BT (Board of Trade, National Archives UK, London) (1959a), BT11/5781, Tel. No. 264, Commonwealth Relations Office to Delhi, 12 October 1959.

BT (1959b), BT11/5781, F.G. Lee to Ranganathan, 2 October 1959; BT11/5781, W. Hughes to Eric Midgley, 12 November 1959.

BT (1959c), BT11/5781, 'EFTA - Compensation for Loss of Contractual Preferences', Midgley, 23 November 1959.

BT (1960a), BT11/5781, Tel. No. 162, Commonwealth Relations Office to Delhi, 9 June 1960.

BT (1960b), BT11/5781, Tel. No. 105, Delhi to Commonwealth Relations Office, 10 May 1960. 
BT (1960c), BT11/5781, Preston to Lacey, TC TC 94/5/1, 18 January 1960.

BT (1960d), BT11/5781, 'EFTA releases/India', Midgley, 20 January 1960.

CMA (Council of Ministers Archives, Brussels) (1958a), CM2/1958/769, Relations des Etats membres de la CEE avec l'Inde, 'Aide-mémoire concernant les relations des Six avec l'Inde établi à l'intention des ministres des Etats Membres appelés à se rendre à New-Delhi à l'occasion de la conférence du Fonds monétaire international', 12 September 1958 and Annex 1.

CMA (1958b), CM2/1958/769, op. cit., 'Consultations au titre de l'article XXII. Demande de consultations avec les Etats membres de la CEE présentée par l'Inde', 15 August 1958 (translation) and aide-mémoire from the Embassy of India, The Hague, not dated.

CMA (1958c), CM2/1958/769, op. cit., Note verbale, Embassy of India, Rome, 13 September 1958.

CMA (1958d), CM2/1958/769, op. cit., Comité des représentants permanents, réunion du $1^{\text {er }}$ octobre 1958, 30 September 1958.

CMA (1958e), CM2/1958/769, Relations des Etats membres de la CEE avec l'Inde, Aide-mémoire concernant les relations des six avec l'Inde établi à l'intention des ministres des Etats Membres appelés à se rendre à New-Delhi à l'occasion de la conférence du Fonds monétaire international, 12 September 1958.

CMA (1959a), CM2/1959/817, Mémorandum du Ceylan, de l'Inde, de l'Indonésie et du Pakistan au sujet des consultations sur le thé, Note d'Information, 27 May 1959.

CMA (1959b), CM2/1959/817, Mémorandum du Ceylan, de l'Inde, de l'Indonésie et du Pakistan au sujet des consultations sur le thé, Réponse au Mémorandum concernant le thé, 13 May 1959.

CMA (1959c), CM2/1959/987, Rapport des conseillers commerciaux des Etats membres de la CEE en Inde, Committee of the Commercial Counselors of the EEC Countries in New Delhi, Meeting of the 29 July 1959, including Annex 1.

CMA (1959d), CM2/1959/987, op. cit., Meeting of 19 August 1959.

CMA (1959e), CM2/1959/987, op. cit., Meeting of 30 September 1959.

CMA (1959f), CM2/1959/987, op. cit., Meeting of the 18 November 1959 and Annex 1 ('Statement on the importance of the European Economic Community by a former Indian Ambassador', The Times of India, 19 November 1959) and 2 (Excerpts from the speech delivered by the Indian Deputy Minister of Commerce and Industry, 6 November 1959).

CMA (1960a), CM2/1960/871, 7ème au 11ème rapports des conseillers commerciaux des Etats membres en Inde, établis en avril et mai 1960, Rapport des conseillers commerciaux des pays de la Communauté économique européenne en Inde, 8ème rapport, 8 April 1960.

CMA (1960b), CM2/1960/871, op. cit., 10ème rapport, 3 May 1960, Annex, 'Trade Problems of Commonwealth. Officials to discuss effect of European set-up', Statesman, 30 March 1960.

CMA (1960c), CM2/1960/871, op. cit., 11ème rapport, 17 May 1960.

CMA (1960d), CM2/1960/872, 12ème au 15ème rapports des conseillers commerciaux des Etats membres en Inde, établis entre juin et novembre 1960, 'Implications of the European Common Market and European Free Trade Association on Trade and Economies of Asian Countries', A Study submitted to the Ninth Session of the Commission on Asian and Far Eastern Affairs of the International Chamber of Commerce to be held in Karachi, 5-9 December 1960, P. Chenstal Rao and H.L. Gupta, Rapporteurs. 
CMA (1960e), CM2/1960/872, op. cit., Treizième rapport des conseillers commerciaux des pays de la CEE en Inde, 6 July 1960 and annexes.

CMA (1961a), CM2/1961/462, Dossier concernant les rapports des conseillers commerciaux des pays de la CEE en Inde, 23.03.1961-01.02.1962, Rapport des conseillers commerciaux des pays de la CEE en Inde, 16ème rapport, 27 March 1961.

CMA (1961b), CM2/1961/462, op. cit., 17ème rapport, 8 May 1961, and annexe III with India's Export Trade with the U.K. and West Europe, World Trade Department, Indian Chamber of Commerce Calcutta, Oxford Book and Stationary Co., Calcutta, 1961.

CMA (1961c), CM2/1961/462, op. cit., 18ème rapport, 25 May 1961 and annexes.

CMA (1961d), CM2/1961/462, op. cit., 23ème rapport, 1 February 1962.

CMA (1962a), CM2/1962/0753, Dossier concernant les négociations tarifaires avec l'Inde dans le cadre du GATT, 24.11.1960-30.05.1961, Négociations avec l'Inde au titre de l'Article XXIX, 22 November 1960, 29 March and Résultats des négociations et/ou des consultations avec le Gouvernement de l'Inde au titre du paragraphe 6 de l'article XXIV.

CMA (1962b), CM2/1962/1033, Dossier concernant les rapports des conseillers commerciaux des pays de la CEE en Inde, Rapport des Conseilleurs commerciaux des pays de la Communauté économique européenne, 26ème rapport, 23 May 1962 and annexes.

DO (Dominions Office, and Commonwealth Relations and Foreign and Commonwealth Offices, National Archives UK, London) (1956a), DO 35/8387, Tel. No. 412, Commonwealth Relations Office to UK Commissioners, 19 October 1956.

DO (1956b), DO 35/8387, Tel. No. 1431, UK High Commissioner in India to Commonwealth Relations Office, 1 November 1956.

DO (1957a), DO 35/8387, Cohen to Lintott, 7 February 1957.

DO (1957b), DO 35/8387, Tel. No. 614, UK High Commissioner in India to Commonwealth Relations Office, 28 May 1957 and Indian Government's Aidememoire, 27 May 1957.

DO (1957c), DO 35/8387, Comité intérimaire pour le Marché Commun et Euratom, 'Document de Travail présenté par la délégation belge', 18 juin 1957 and English translation 'Belgian reply to the Indian aide-mémoire of 27th May 1957 .

DO (1957d), DO 35/8387, Heath to Simons, 3 September 1957.

DO (1957e), DO 35/8387, Norgan to Hack, 10 September 1957.

DO (1957f), DO 35/8387, Tel. No. 1199, UK High Commissioner in India (Acting) to Commonwealth Relations Office, 1 October 1957.

DO (1957g), DO 35/8387, Tel. No. 1856, Commonwealth Relations Office to UK High Commissioner in India (Acting), 4 October 1957.

Giri, D.K. (2001), European Union and India: A Study in North-South Relations, New Delhi: Concept Publishing Company.

Johnson, G.A. (1946), 'European Regionalism', India Quarterly, 2 (2) (May).

Kumar, D. (1966), India and the European Community, London: Asia Publishing House.

Lall, K.B. and H.S. Chopra (1984), 'The EEC and India', in K.B. Lall, W. Ernst and H.S. Chopra (eds), India and the EEC, New Delhi: Allied Publishers.

Lokanathan, P.S. (1951), 'Regional Economic Co-operation in Asia', India Quarterly, 7 (1) (January-March). 
Macmillan, H. (1971), Riding the Storm 1956-59, New York: Harper and Row.

McCallum, J.A. (1947), 'The Asian Relations Conference', The Australian Quarterly, 19 (2) (June), 13.

Mookerjee, G. (1949), 'Steps Towards European Unity', India Quarterly, 5 (3) (July-September).

Moorthy, K.K. (1984), 'Some Positive Aspects of Collaboration with the EEC', in K.B. Lall, W. Ernst and H.S. Chopra (eds), India and the EEC, New Delhi: Allied Publishers.

Pannikkar, K.M. (1946), 'Regionalism and World Security', India Quarterly, 2 (2) (May).

Van Mensbrugghe, J. (1949), 'Benelux', India Quarterly, 5 (1) (January-March).

Venkatasubbiah, H. (1949a), 'Prospects of an Asian Union: Lessons from the Organization of American States', India Quarterly, 5 (2) (April-June).

Venkatasubbiah, H. (1949b), 'Prospects of an Asian Union II', India Quarterly, 5 (3) (July-September). 